\title{
(Un)Leash the Self: \\ Exploring Frontiers in (Re)writing America
}

\author{
Reem Eldegwi*
}

\section{Introduction}

Upon reading Julia Alvarez's How the García Girls Lost their Accents (1991; henceforth referred to as García Girls) and Sandra Cisneros' The House on Mango Street (1984; henceforth referred to as Mango Street) it becomes clear that both writers cross borders while representing their cultures from within a whole-white American environment. This provides a new perspective with which their attempt at formulating their identities can be seen; an outlook that stems from the fact that Alvarez and Cisneros stand the positionality of being American with a hyphenated identity, where their writings exhibit an illustration of the transnational dimension that literature assumes.

The term transnationalism has been defined and discussed by many a scholar; for example, Donald E. Pease and Yuan Shu argue in their introduction to ReFraming the Transnational Turn in American Studies that "the term 'transnational' has replaced 'multicultural,' 'postcolonial,' and 'postnational' as the most frequently invoked qualifier" $(2015,2)$. It is a term that predetermines not just the understanding of the two texts at hand, but at the same time allows for a reconceptualization of issues such as identity, voice, and positionality, among others. Along the same lines, Bieger, Saldívar, and Voelz suggest in the introductory pages of The Imaginary and Its Worlds: American Studies after the Transnational Turn that " $[\mathrm{t}]$ he field of 'transnational American Studies' is growing with breathtaking rapidity, generating work on a wide range of cultural, political, and economic configurations that reach across national boundaries and change our views of what is situated within them" (2013, vii). Hence, the two texts at hand, García Girls and Mango Street, involve such 'configurations' in a process where many borders intersect while being crossed. Bieger, Saldívar, and Voelz contend that the transnational world "bring[s] the force of imagination, as both memory and desire, into the lives of many ordinary people, into

\footnotetext{
* Lecturer in Comparative Literature, Department of English Language and Literature, Faculty of Arts, Cairo University.

Cairo Studies in English - 2020(2): https://cse.journals.ekb.eg/
} 
mythographies different from the disciplines of myth and ritual of the classic sort" (2013, vii). And to a great extent, this is what Alvarez and Cisneros could be seen doing in their two texts examined in this paper: they depict their 'ordinary' characters in a manner that is not "bound by national boundaries and exceptionalism" (vii). ${ }^{1}$ Rather the two writers can be taken to imagine a new perception of exceptionalism by means of which the power paradigms that exist between the US and its subjects could be revisited, and the moulds of identity could be dismantled.

Actually, Alvarez and Cisneros' 'imaginary' embodied through the worlds of both characters, Yolanda and Esperanza, "brings forward a world that is less exclusionary and exceptionalist, more porous, overlapping, and cosmopolitan than traditional world views based on national boundaries" (Bieger et al. 2013, $\mathrm{x})$. The imaginary is "a category of reflection," one which "brings forth communities, not as illusions but as realities" (x). In this sense, Alvarez and Cisneros are bringing their ethnic groups to the foreground while writing about America. It is an America where those groups are a reality, struggling for acceptance, and theirs is a reality that crosses several borders: temporal, spatial, linguistic, geographical, and psychological. It is this 'imaginary' of Alvarez and Cisneros that can be considered as "an intercultural and transnational construct based on the shared desire to transcend the constraints of ethnicity or any national particularity." (Pease and Shu 2015, 26)

Similarly, the writers' attempts are in actuality "seeking to heal the fractures and ruptures resulting from exile and dispersal" (Stefanko 1996, 50), where their characters engage in a constant border-crossing: "As migrant souls traveling/dwelling in diverse cultural spaces, Latina writers become embedded within the process of translation" (51). Not only does this process reflect a linguistic border-crossing, but it also encompasses other borders as well; it "accompanies any other shifts across boundaries" (51). Represented as belonging to ethnic groups whose endeavor is to come to terms with the self and other while crossing the borders that come along the way, Yolanda and Esperanza's experience in the US is harsh and severe because as members of an excluded group, they share what Lionel Trilling describes as "the same notion of life and the same aspirations as the excluding group" (qtd. in Rowe 2011, 5). In this light, this article examines how in doing so they engage in writing America, or rather re-writing it, creating a new frontier that serves as a space of accentuating who they are and, simultaneously, what the American Empire is like. 


\section{Losing Accents While Crossing Borders}

In García Girls, Julia Alvarez tells the story of the García sisters-Carla, Sandra, Yolanda, and Sofia - and their family who must flee their home in the Dominican Republic after their father's role in an attempt to overthrow a tyrannical dictator is discovered. In the novel narrated mostly by Yolanda, they arrive in New York City in 1960 to a life that is far removed from their existence in the Caribbean. Thus, the element of crossing borders is highlighted from the very beginning making it plausible to read the text "not as a fixed geographical, ethnically or nationally bound category of writing" (Stefanko 1996, 55), but rather "a series of boundary crossings" (55) that engage the García sisters, Alvarez herself, and by extension the reader. ${ }^{2}$

As Yolanda divulges her memories of the family's last day on the Dominican island, she instantly highlights the nature of the journey they have to take to the American land of freedom that is supposed to provide a refuge away from the dictatorship back home:

So here's the part I remember about that last day. Once Nivea left the room, Chucha stood us all up in front of her. "Chuchas -" she always called us that [...] "You are going to a strange land." Something like that, I mean, I don't remember the exact words. But I do remember the piercing look she gave me as if she were actually going inside my head. "When I was a girl, I left my country too and never went back." (Alvarez 2004, 220-1, emphasis mnie)

Along with the accentuated strangeness of the new land, or rather the New World, a whole experience of crossing borders is being framed. ${ }^{3}$ As Jacqueline Stefanko argues that "crossing enables the reader and writer to participate in the breaking down of constructed, pure boundaries and to engage in complex heterogeneous dialogues" (1996, 51), James Clifford similarly contends that "unresolved historical dialogues between continuity and disruption, essence and positionality, homogeneity and differences (cross-cutting 'us' and 'them') characterize diasporic articulations" $(1992,108)$. In this light, the García journey to this strange land is peculiar in its singularity that is rooted in the physical and mental back and forth movement.

In this new world that is not always welcoming, their parents try to hold on to their old ways, but the girls try to find new lives, and to cross borders by forgetting their language, straightening their hair, and wearing bell bottoms. For them, it is both liberating and excruciating to be engrossed in the two worlds 
they belong to. And perhaps it is in these two worlds that borders are being constantly crossed, redefined, and blurred at times. As suggested by the title of the novel, there is an inevitable sense of loss in which the García girls are entrapped; not only do they lose their accents, but they experience loss on several levels. Helen Yitah contends that "while the word 'accents' in the novel's title suggests a linguistic loss, the novel seems as much about the loss of their native Spanish as it is about their loss of a firm grasp of their turning world" (2003, 234). It becomes clear from Yolanda's narration of the novel in most of its parts that the sisters' displacement resulting from their immigration, or rather escape, to the US has come at a great cost. Their hope for being welcomed in a country that is supposed to be their safe refuge from the atrocities of dictatorship at home gets shattered once they land in America. This culminates in a sense of loss of both their identity (who they are and where they belong) and, consequently, their self-worth, where "the profound linguistic dislocation and the resultant disorientation that the young girls experience in the United States combine to erode their self-assurance and deny them any stable sense of self" (Yitah 2003, 234). This is basically highlighted in the protagonist's experience where "Standing here in the quiet, she believes she has never felt home in the States, never" (Alvarez 2004, 12). Yolanda, as her sisters, has already lost the sense of home when she goes to the US; therefore, no matter how hard her attempts are to cross the psychological border of loss, she ends up further alienated with a blurred self-image.

From another dimension, Yolanda's psychological loss is further intensified through "negotiating issues of language, specifically the border-crossing of translation and bilingualism" (Stefanko 1996, 59). A significant example is her proliferation of names which advocates "the multiplicity of her identity" (59). She points out: "Yolanda, nicknamed Yo in Spanish, misunderstood Joe in English, doubled and pronounced like the toy, Yoyo - or when forced to select from a rack of personalized key chains, Joey" (Alvarez 2004, 68). This highlights her disintegrated identity and fragmented self; she finds it extremely difficult to connect with the parts constituting that self: "Through the creative medium of language, the active interpretation of translation, Yolanda is established on the hyphen where she can shift among subject positions and worlds" (Stefanko 1996, 60). As made clear, Yolanda painstakingly attempts to cross the linguistic border only to find herself levelled with 'crazy' people, or those who are psychologically disturbed. Her boyfriend, John, cannot really understand her when she tries to explain herself, translating her Spanish into English and, consequently, allocating to her a place of craziness: "What you need is a goddam 
shrink!" (Alvarez 2004, 73). ${ }^{4}$ Thus, the English language Yolanda uses does not express what her Spanish could not say, rather what was said but not really understood. Accordingly, John's reaction towards Yolanda's attempt to cross the linguistic border can be seen in light of David W. Noble's assertion that hyphenation is often "a form of external labeling that applies the whims and the interests of the dominant onto the subject" $(2002,44)$. Hence, Yolanda is left entangled within a sense of loss; a feeling of "unhomeliness," to use Bhabha's term, ${ }^{5}$ with which she struggles until it finds its way to appeasement through the space she creates for herself through writing.

Not only can Yolanda's resolution to shift to writing be marked as an attempt by means of which "she can harmonize the multiple selves that make up her identity" (Yitah 2003, 239), but, simultaneously, hers is an endeavor to overcome and transcend the insurmountable barriers that she struggles with. In Yolanda's situation, writing appears to be a safe space where she can experiment with her journey of self-exploration, the santo and the antojo that haunt her journey. ${ }^{6}$ In other words, writing enables Yolanda to conquer her displacement, subdue "the santo who has taken over [her]," America that is, and "quench the antojo," the nostalgic craving of the homeland (Yitah 2003, 238). Alvarez clarifies:

Back in the Dominican Republic growing up, Yoyo had been a terrible student. No one could ever get her to sit down to a book. But in New York, she needed to settle somewhere, and since the natives were unfriendly, and the country inhospitable, she took root in the language. By high school, the nuns were reading her stories and compositions out loud in English classes. (Alvarez 2004, 141)

It is true that language is the tool Yolanda uses to "reach across worlds, to transcend the barriers or differences" created by her dislocation and the resultant experience of border-crossing (Yitah 2003, 240); however, it never comes as a facile task. Yolanda herself admits that when she was supposed to give a speech at school, "the spectre of delivering a speech brown-nosing the teachers jammed her imagination. At first, she didn't want to and then she couldn't seem to write that speech" (Alvarez 2004, 141). As could be suggested, no matter how difficult it is, language is a tool employed by Yolanda to claim a space that can enable her to formulate an identity shaped by the borders separating/connecting the two cultures that mold her experience. Thus, Helen Yitah contends, "it is not a question of choice between her original and adopted cultures, but some balance 
of both to form a synergy from which a new identity, indebted to both but identical to neither, emerges" (Yitah 2003, 239).

From a different perspective, the English language does not present itself only as a mode of expression by means of which Yolanda can formulate her identity, but it is also depicted as a form of protection. Ironically, when her car does not start during her trip while looking for guavas back in the Dominican Republic, it is the English language that saves her; she resorts to English to save herself from her fears of the farm labourers. As suggested by Yitah, "[T]he fact that she is compelled to be and speak English at such a critical moment reveals the extent of her feelings of loss and explains her determination to recover herself' (2003, 242-3). Those feelings of loss are compensated for, or substituted by, what the adopted/host culture of the US offers; it aligns with David W. Noble's contention that " $[t]$ he attempted erasure of cultures and languages in the US political space has been (and is yet) carried out under the guises of the democratic justification, allowing the enterprise to appear appropriate if not organic" $(2002,34)$. In order to protect herself, Yolanda has to use the English language not just due to the fact that it ensures her salvation, but because it is appropriate as well.

\section{Crossing Borders to a House of One's Own}

In Mango Street, Sandra Cisneros weaves the action of a collection of vignettes that span a year in the life of Esperanza, a young teenager, who has moved with her family to Mango Street in Chicago. Not only does Esperanza track her experience living in that house and that poor neighbourhood, but she also follows the lives of other neighbours who live around. She wishes to escape her impoverished life and to cross the borders imposed by financial and economic hurdles, to then return one day to rescue other girls there. The young girl explores the plight of the marginalised Latinos struggling to survive in a dominantly white country.

Julian Olivares argues that according to Cisneros herself the novel "hover[s] in that grey area between [...] genres" $(1987,160)$, which sheds light on the genre-defining borders which the author crosses. Hence, Cisneros and Esperanza alike engage in a process of transcending the boundaries that shape the experience of each of them. It is from the outset of the text that Esperanza asserts "The house on Mango Street is ours ... But even so, it's not the house we'd thought we'd get" (Cisneros 1984, 3). This is an important statement on Esperanza's part that both holds the readers' informed understanding of the protagonist's border-crossing and equally draws attention to Esperanza's relationship with this house. On one level, it becomes clear that there has been a 
constant movement from one house to another until Esperanza's family manages to own one. The physical movement underscored here mirrors the borders Esperanza engages in; she struggles, first and foremost, with the psychological border brooding upon her experience in the US owing to the fact that she has never lived in a house that she can point to. The shabby house with its peeling paint stands for the harsh reality and the shattered dreams of the Hispanic family including Esperanza; life in the US has not been as promising as they have desired it to be, and so is the house. In light of Bill Ashcroft's definition of habitation as "a way of being in a place, a way of being which itself defines and transforms place" $(2001,15)$, it is evident how Esperanza's place in that house in the barrio aggravates her exclusion from the whole-white American community. It neither represents her nor alleviates the hideous consequences of her exclusion; in other words, "habitation, in its reconfiguration of conceptions of space, also engages the most profound principles of Western epistemology: its passion for boundaries, its cultural and imaginative habits of enclosure" (Ashcroft 2001, 16). Hence, Esperanza's entrapment in a process of constant border-crossing is ineluctable while being enforced upon her by the exclusionary power paradigms of the host culture/country.

To her predicament, it is not just the house that has failed Esperanza; her name burdens her equally. After highlighting the feelings of dislocation and exclusion that are encompassed within the house she cannot point to, Esperanza admits that the meaning of her name is not the same in Spanish as it is in English; thus, intensifying her sense of dislocation while bringing under the spotlight the linguistic border within which she is ensnared. She admits: "In English my name means hope. In Spanish it means too many letters. It means sadness, it means waiting" (Cisneros 1984, 11). The different meanings of her name tell of her fractured identity and depict the impact of the two-fold barrier she has to cross; she becomes entrapped in a state of "unhomeliness" (to use Bhabha's term), which further aggravates her exclusion. It is not surprising then that she fosters a tendency to change the name she has inherited from her grandmother, one that has blurred her identity; she states: "I would like to baptize myself under a new name, a name more like the real me, the one nobody sees" (Cisneros 1984, 11). Esperanza's tendency to change her name can be an attempt on her part to figure out who she is and to formulate her identity, and her real self; this reveals her desire to be exonerated from a cultural burden and absolved of the cultural clash, while transcending the boundaries present between her home and host cultures. The new name Esperanza aspires for is rooted deeply in her desire to break away from the feelings of displacement fostered by the exclusionary American culture, 
and that cause many of the Hispanic women "to sit their sadness on an elbow," hence, her decision not to "inherit [the grandmother's] place by the window" (Cisneros 1984, 11). As Olivares argues, "Cisneros inverts Bachelard's nostalgic and privileged utopia" $(1987,160)$ making Esperanza's reality a different one; it is a reality inherent in her experience as a Chicana living in the inhospitable, aggressive barrio in which she must learn how to cross the borders of her fractured identity and to transcend the boundaries of her two intersecting worlds.

Maria Elena de Valdés endorses Naomi Black's social feminist view through which Esperanza seems to use "the doctrine of difference not to obliterate differences of kind, but to change a society that uses difference as a basis for exclusion" (1992, 55). She is determined to assert herself and formulate an identity in a society that marginalizes her, creating more borders for her to cross. Interestingly, she learns the necessary strategies from the four skinny trees with which she communicates and identifies. The analogy Cisneros weaves between Esperanza's situation and that of the four skinny trees "who do not belong here but are here" (Cisneros 1984, 74) is significant as they mirror Esperanza's adamant resolution to cross the boundaries that come along her way. Against all odds, she will have to transcend those boundaries like the trees that also cross the boundaries of difference and exclusion:

Their strength is secret. They send their ferocious roots beneath the ground. They grow up and they grow down and grab the earth between their hairy toes and bite the sky with violent teeth and never quit their anger. This is how they keep. (Cisneros 1984, 74)

Not only do the trees inspire Esperanza into holding strongly to her "reason for being" (Cisneros 1984, 74), but they shed light on the inevitability of crossing borders along her journey of self-exploration/realization. They provide her with strength, teach her tactics of survival, and guide her in order to "reach and [not] forget to reach" (Cisneros 1984, 75). The word "reach" signifies the process of border-crossing that Esperanza engages in, especially the linguistic one since it is through using language/writing that she manages to keep like the trees, realise her true self and cross borders. It is due to the fact that "The semes that we ordinarily perceive in house [...] such as comfort, security, tranquility, esteem are lacking" (Olivares 1987, 167) and which she has been inspired by the trees to "keep" and "reach," Esperanza admits: "I knew then I had to have a house. A real house. One I can point to" (Cisneros 1984, 5). She is only capable of doing so by reverting to language/writing that can guarantee her a space/house of her 
own. As suggested by De Valdés, Esperanza "probes into her world, discovers herself and comes to embody the primal needs of all human beings: freedom and belonging" $(1992,60)$. She has to unleash her own self through writing in order to enjoy those 'primal needs' away from the restraints imposed by exclusion and borders. Cisneros' protagonist subverts the exclusionary dialectics and subdues the power paradigms by using the language of the host culture/country in order to cross the borders that have silhouetted her journey. In other words, Esperanza's “'home', like 'place', becomes freed from a simple spatial concept of location. It becomes a way of inhabiting and, ultimately, transforming global discourses of power by seeing 'at home' in them whatever local appropriations that may entail" (Ashcroft 2001, 197). This is true of Esperanza who manages to put the pieces of her fractured self and cross borders by finding refuge, a comfortable 'at home' zone that allows her a new space/place to move within and articulate who she really is.

\section{Conclusion}

Both Alvarez and Cisneros' portrayal of their protagonists within such contexts emphasizes that the

dimensions of transnational American Studies (in a cultural sense) are predicated on the idea that 'America' exists as a unified concept and should be studied as though the people who reside in spaces claimed by the US political body have some sense of being that is dependent or otherwise relational to the promulgated set of cultural myths. (Noble 2002, 6)

One of such cultural myths is the notion of 'American exceptionalism,' where the American culture broods upon the getaway which both Yolanda and Esperanza resort to, namely language/writing. Both retreat to English in order to be able to cross the borders that come along their journey of selfidentification/realization. They venture to claim a transnational space "where one never belongs totally to one place, yet where one is able to feel an integral part of many places" (Stefanko 1996, 67). However, in doing so, they leave the reader wondering about the legitimacy of the superiority of the American culture, its hegemonic power, and discernible exceptionalism. It is valid to see Alvarez and Cisneros's texts as distinct attempts at "imagining other positions and values" (Rowe 2011, 4) different from their own. Yolanda and Esperanza's firsthand experience of being an American with a hyphenated identity allows 
them to rewrite America. It is an exceptional America where a Chicano can acquire the unalienable American rights of 'life, liberty and the pursuit of happiness,' only by clinging to the dialectics promulgated for by the American culture.

Yolanda and Esperanza are uncertain as to where they really belong, the home country, or the host one; accordingly, crossing borders - whether psychological, linguistic, geographical, etc. - seems inevitable given the protagonists' desire to explore, identify, and realise themselves. As Silvio Sirias contends, "it is [their] difficulty with [their] Americanization that leads to that ambition" (2001, 25); thus, they opt for the written word and English, "a language other than [their] native one, to do so" (25). Therefore, Yolanda and Esperanza's mandatory conformity with what the American culture dictates upon them highlights the inescapable supremacy imposed by the US culture; they had no other option, or else they would be 'othered' and remain excluded: "The intended outcome, then, is to limit the constitution of $I$ and subsequently we of the residents of the space to a set of norms that reiterates the power of those who control the structures" (Noble 2001, 35); that is America.

\section{Endnotes}

${ }^{1}$ According to Donald E. Pease, American exceptionalism means that "America is either 'distinctive' (meaning merely different), or 'unique' (meaning anomalous), or 'exemplary' (meaning a model for other nations to follow), or 'exempt' from the laws of historical progress (meaning that it is an 'exception' to the laws and rules governing the development of other nations)" (Pease n. pag.). A close examination of the meanings attributed to the term and a deeper look at the history of America make it evident that American Exceptionalism cannot solely be held as a valid term; it is, simultaneously, an ideology that promotes, confirms, and consolidates the image of the USA as a shining "city upon a hill". This image holds strong grounds owing to the fact that the "American mix of Enlightenment theory and practical experience in government produced a result that was seen from the first as - there is no other word for it exceptional" (Guelzo n. pag.).

${ }^{2}$ Alvarez, born and raised in the Dominican Republic, had to leave the country and flee to Brooklyn, New York when she was a ten-year-old girl due to the fact that her father had supported an unsuccessful attempt to overthrow the dictator Rafael Trujillo. Accordingly, traces of Alvarez's personal life can resonate in 
Yolanda's own experience, making the process of crossing borders relevant to both author and protagonist.

${ }^{3}$ The term 'New World' unyieldingly takes back to the time when the European settlers first set foot on the American continent. As Reingard M. Nischik suggests, "Vespucci's term 'New World' thus indirectly also refers us back to the fact that America, from a European perspective, was invented rather than "discovered" "which presents "a projection screen for many powerful dreams and myths" (2016, 11). Thus, Vespucci's New World is juxtaposed with the one where the García girls have their dreams enveloped by the myths about America, and where the process of crossing borders is constant.

${ }^{4}$ This kind of lack of understanding on her boyfriend's part tells of how the American and Latino cultures are: "when not engaged in outright war, [they] have been consistently hostile to each other" (Firmat 2003, 10).

5 By applying Homi Bhabha's concept of 'unhomeliness' to Yolanda, she is 'unhomed,' where 'unhomely' refers to the "uncanny literary and social effect of enforced social accommodation, or historical migrations and cultural relocation" $(1992,141)$.

${ }^{6}$ As Helen Yitah argues, it is through the constant crossing of borders/boundaries that Yolanda engages in, she realizes her true "antojo," her desire to identify herself in a way that is void of the pressures imposed on her whether at home in the Dominican Republic, or in the US, or even in her attempts to jump the puddles with which the ongoing process of crossing is affluent $(2003,239)$.

\section{Works Cited}

Alvarez, Julia. 2004. How The García Girls Lost their Accents. Bloomsbury: London.

Ashcroft, Bill. 2001. Colonial Transformation. New York: Routledge.

Bieger, Laura, Ramón Saldívar and Johannes Voelz. 2013. "Introduction." In

The Imaginary and Its Worlds: American Studies after the Transnational Turn, edited by Laura Bieger, Ramón Saldívar and Johannes Voelz, vii-xxviii. Hanover, New Hampshire: Dartmouth College Press.

Bhabha, Homi. 1992. "The World and the Home." Social Text 31/32: 141-53.

Duke University Press. $<$ http://www.jstor.org/stable/466222>.

Cisneros, Sandra. 1984. The House on Mango Street. New York: Vintage Books. Clifford, James. 1992. "Travelling Cultures." In Cultural Studies, edited by Laurence Grossberg, Cary Nelson and Paula A. Treichler, 96-116. New York: Routledge. 
De Valdés, Maria Elena. 1992. "In Search of Identity in Cisneros' The House on Mango Street." The Canadian Review of American Studies 23, no. 1 (Fall): 55-72.

Firmat, Gustavo Perez. 2003. Tongue Ties: Logo-Eroticism in Anglo-Hispanic Literature. New York: Palgrave Macmillian.

Guelzo, Allen C. 2019. "What's Exceptional About American Exceptionalism?"

City Journal (Summer): n. pag. <https://www.city-journal.org/americanexceptionalism>.

Nischik, Reingard M. 2016. Comparative North American Studies: Transnational Approaches to American and Canadian Literature and Culture. New York: Palgrave Macmillian.

Noble, David W. 2002. The Death of a Nation: American Culture and The End of Exceptionalism. Minneapolis: University of Minnesota Press.

Olivares, Julián. 1987. "Sandra Cisneros' The House on Mango Street and the Poetics of Space." Americas Reviews 15, no. 3-4 (Fall/Winter): 160-70.

Pease, Donald E. 2018. "American Exceptionalism." Oxford Bibliographies. June 27, 2018. <https://www.oxfordbibliographies.com/view/document/obo9780199827251/obo-9780199827251-0176.xml>.

----- and Yuan Shu. 2015. "Introduction.” In American Studies as Transnational Practice Turning toward the Transpacific, edited by Donald E. Pease and Yuan Shu, 1-35. Hanover, New Hampshire: Dartmouth College Press.

Rowe, John Carlos. 2011. Afterlives of Modernism: Liberalism, Transnationalism, and Political Critique. Hanover, New Hampshire: Dartmouth College Press.

-----, Winfried Fluck and Donald Pease, eds. 2011. Re-Framing the Transnational Turn in American Studies. Dartmouth University Press: University of New England.

Sirias, Silvio. 2001. Julia Alvarez: A Critical Companion. Westport, CT: Greenwood Press.

Stefanko, Jacqueline. 1996. "New Ways of Telling: Latina's Narratives of Exile and Return." Frontiers: A Journal of Women Studies. 17, no. 2: 50-69. University of Nebraska Press. <http://www.jstor.org/stable/3346592>.

Yitah, Helen Atawube. 2003. “'Inhabited by Un Santo': The 'Antojo' and Yolanda's Search for the 'Missing' Self in How the García Girls Lost Their Accents.” Bilingual Review 27, no. 3 (Jan.): 234-43.

$<$ https://www.researchgate.net/publication/254134273>. 